\title{
Pola stoljeća hrvatske politike (1895. - 1945.) u korespondenciji između Dominika Mandića i Jere Jareba
}

Marina Beus

Filozofski fakultet

Matice hrvatske b.b.

BiH - 88000 Mostar

E-mail: marina.beus@ff.sum.ba
UDK: 32(497.5)"1895/1945"

929 Mandić D.

929 Jareb J.

Prethodno priopćenje

Primljeno: 21. ožujka 2018.

Prihvaćeno: 30. svibnja 2018.

\section{Sažetak}

U bogatoj korespondenciji između Dominika Mandića i Jere Jareba, nastaloj u razdoblju od 1953. do 1972. godine nalaze se i četiri pisma koja su tematski povezana s Jarebovim uratkom Pola stoljeća hrvatske politike (1895. - 1945.). Posebna pozornost usmjerena je na dva pisma iz siječnja 1960., u kojima dvojica povjesničara vode znanstvenu polemiku po pitanju jugoslavenske narodne i državne ideje, te odnosa ondašnjih političkih aktera prema toj ideji.

Ključne riječi: Dominik Mandić; Jere Jareb; jugoslavenstvo; hrvatska politika; Hrvatska pučka stranka; Hrvatski katolički pokret. 
Marina Beus - Pola stoljeća hrvatske politike (1895. - 1945.)...

\section{Uvod}

Arhiv Hercegovačke franjevačke provincije među inom građom čuva i ostavštinu poznatoga hercegovačkog franjevca Dominika Mandića. ${ }^{1}$ Iako se u posljednje tri godine pojavilo nekoliko radova, među kojima svakako najznačajnije mjesto zauzima zbornik radova sa znanstvenoga skupa u povodu 40. obljetnice smrti fra Dominika Mandića, ${ }^{2}$ činjenica je da sačuvana bogata ostavština stavlja pred povjesničare vrlo dragocjenu građu koja omogućava ne samo daljnje rasvjetljavanje životnoga puta fra Dominika Mandića, bilo kao redovnika, kao znanstvenika ili pak političara, nego omogućava sklapanje mozaika koji razotkriva političke prilike u kojima je živio, njegove političke zaokrete, te pothvate koje je u suradnji s drugim znanstvenicima raznih profila, u posljednja dva desetljeća svoga života poduzimao, kako bi pomogao u promicanju hrvatskoga imena i hrvatske povijesti. Jedan od uglednih znanstvenika s kojim je fra Dominik Mandić nakon svoga dolaska u Chicagu vrlo često komunicirao bio je i hrvatski povjesničar Jere Jareb. ${ }^{3}$ Naime, iz sačuvane fra Dominikove

1 Opširnije o njegovu životopisu: Arhiv HercegovačKe franjevačKe Provincije (dalje: AHFP), Mandićeva ostavština (dalje: MO), sv. 19, m. 3, f. 1-48; Bazılıje Pandžıć, Životopis dr. fra Dominika Mandića, OFM, Chicago, 1994. Vidjeti Mandićev autobiografski tekst: "Curriculum vitae" u: RoBERT Jolić (prir.), Dr. fra Dominik Mandić (1889.-1973.). Zbornik radova sa znanstvenoga simpozija održanog u prigodi 40. obljetnice njegove smrti, Hercegovačka franjevačka provincija Uznesenja BDM - Franjevačka knjižnica Mostar - Hrvatski institut za povijest, Mostar - Zagreb, 2014., str. 13-39.

Robert Jolić (prir.), Dr. fra Dominik Mandić (1889.-1973.).

3 Jere Jareb bio je istaknuti hrvatski povjesničar koji je svoju znanstvenu karijeru najvećim dijelom izgrađivao u SAD-u gdje se našao u političkoj emigraciji od 1952. godine. Bio je jedan od osnivača Hrvatske akademije Amerike (Croatian Academy of America), koja je pokrenuta 1953. godine, prvi izvršni tajnik, a od 1982. - 1988. godine i predsjednik Akademije, te povjerenik časopisa Hrvatska revija. Najveći broj svojih radova objavio je upravo u časopisima Journal of Croatian Studies (pokrenut u sklopu Hrvatske akademije Amerike 1960. godine) i Hrvatskoj reviji u čijem je izdanju 1960. godine tiskana i njegova prva knjiga Pola stoljeća hrvatske politike 1895.-1945. Povodom Mačekove autobiografije. Drugo izdanje ove knjige tiskano je nakon proglašenja samostalne Hrvatske, točnije 1995. kada Jere Jareb ostvaruje intenzivnu suradnju s ondašnjim Institutom za suvremenu povijest, odnosno kasnije njegovim slijednikom Hrvatskim institutom za povijest, čiju je izdavačku djelatnost dopunio dvjema dragocjenim zbirkama izvora za povijest Nezavisne Države Hrvatske (Zlato i novac Nezavisne Države Hrvatske izneseni u inozemstvo 1944. i 1945. i Državno gospodarstveno povjerenstvo Nezavisne Države Hrvatske od 
ostavštine korespondencija dvojice povjesničara započela je 1953. godine, što je dakako povezano s Mandićevim preuzimanjem starješinstva Hrvatskoga komisarijata u SAD-u (krajem veljače 1952.) i njegova trajnoga nastanjenja u Chicagu. ${ }^{4}$ Iz sadržaja četrdesetak pisama (razmijenjenih u razdoblju od 1953. do 1972. godine) vidljivo je da su Mandić i Jareb prvenstveno surađivali kao povjesničari, ali i kao osobe koje iskazuju veliki senzibilitet za izdavaštvo među mnogobrojnim hrvatskim emigrantima. ${ }^{5} \mathrm{U}$ tom smislu i jedan i drugi, svatko u svome okruženju, uključuju se u osnivanje institucija koje će, za razliku od ondašnje jugoslavenske cenzurirane historiografije, omogućiti otvoreniji znanstveni pristup u istraživanju i sagledavanju hrvatske kulture i povijesti, ne samo među hrvatskom emigracijom, nego i širom svjetskom javnošću. Budući da je u 3. bilješci ovoga rada već ponešto rečeno o Jarebovu angažmanu u Hrvatskoj akademiji Amerike, te Hrvatskoj reviji, valja istaknuti da je i fra Dominik Mandić nakon dolaska u Chicago, u proljeće 1953. godine, također utemeljio Hrvatski izdavački zavod "Croatia", koji preuzima izdavanje Hrvatskoga kalendara, a gašenjem Zavoda, izdavaštvo preuzima novoosnovani Hrvatski povijesni institut, čije će središte od 1963. godine biti u Rimu. ${ }^{6}$ Upravo poslovi na uređivanju i izdavanju časo-

kolovoza 1941. do travnja 1945. godine). Objavio je također i niz članaka u Časopisu za suvremenu povijest i Hrvatskoj reviji. U 95. godini života preminuo je 21. studenoga 2017. u Charlottesvilleu (Virginia) u SAD-u. Opširnije o Jarebovu životu i radu vidjeti u: Hrvoje Matković, "Razgovor s dr. Jerom Jarebom u povodu 80. godišnjice njegova života", u: Časopis za suvremenu povijest, Zagreb, 3/2008., str. 709-728; http://arhiv.slobodnadalmacija.hr/20030127/feliton01.asp, Vesna Kukavica, Promicateljska Hrvatska akademija Amerike (5. 2. 2018.); MARio JAREB, "Jere Jareb (3. svibnja 1922. - 21. studenoga 2017.)", u: Časopis za suvremenu povijest, Zagreb, 3/2017., str. 616-617; http://www. enciklopedija.hr/Natuknica.aspx?ID=28758 (5. 2. 2018.).

4 AHFP, MO, sv. 5, m. 1, f. 78-79.

5 Mandićevo dopisivanje s Jerom Jarebom: AHFP, MO, sv. 5, m. 2; sv. 6, m. 1, 4; sv. 7, m. 1-4; sv. 9, m. 2; sv. 11, m. 1; sv. 20, m. 2; sv. 25, m. 2.

6 U Mandićevoj ostavštini sačuvan je velik broj dokumenata (pisma suradnicima, pristupnice, promidžbeni materijal, donacija...) vezanih za osnutak i djelovanje kako čikaškoga, tako i rimskoga Hrvatskog povijesnog instituta, a neki od njih su: AHFP, MO, sv. 20, m. 4, pm. A, f. 1-337; sv. 6, m. 2, f. 217, 228; sv. 6, m. 3, f. 16, 42, 61-66, 79; sv. 6, m. 4, f. 88, 93, 104, 117, 152, 173, 197, 198-199; sv. 6. m. 5, f. 76; sv. 7, m. 4, f. 65; sv. 8, m. 4, f. 106; sv. 14, m. 1, pm. 1, f. 2. Usp. Mario Jareb, "Mandićev odnos prema hrvatskoj (i inoj) političkoj emigraciji za vrijeme i nakon Drugoga svjetskog rata", u: RoBERT JolIć (prir.), Dr. fra Dominik Mandić (1889.-1973.), str. 573-574. 
pisa Hrvatski kalendar, Journal of Croatian Studies i Hrvatska revija, kao što se uočava iz njihove korespondencije, povezat će fra Dominika Mandića i Jeru Jareba. Naime, Jareb osim što je iz New Yorka pomagao Mandiću u pronalasku nekih publikacija i izvora, također je objavljivao, a povremeno prevodio i ocjenjivao, radove povijesnoga karaktera koji su objavljivani u raznim publikacijama koje je fra Dominik priređivao, dok je s druge strane Mandić redovito objavljivao radove ili priloge u Hrvatskoj reviji, a jedan rad objavio je u prvom broju Journal of Croatian Studies. ${ }^{7}$ Međutim, možda najbitnija stavka iz ove korespondencije jest nezaobilazna činjenica da su dvojica uglednih povjesničara, cijeneći obostrani znanstveni objektivizam, razmjenjivali i znanstveno-kritička promišljanja o bliskim im povijesnim temama. Jedna od tih tema bila je, i u tome razdoblju, pripremana prva knjiga Jere Jareba Pola stoljeća hrvatske politike 1895. - 1945. Povodom Mačekove autobiografije, koja je, kako sam autor u svome pismu Dominiku Mandiću od 23. studenoga 1959. naglašava, utemeljena na njegovoj trodijelnoj raspravi (Pola stoljeća hrvatske politike) objavljenoj u Hrvatskoj reviji tijekom 1959. godine. Stoga u ovom pismu Jareb moli Mandića da pažljivo pročita sva tri dijela njegove rasprave kako bi ga mogao upozoriti na eventualne činjenične pogrješke ili mu pak dati savjet kada je riječ o dopunama iznesenih činjenica, odnosno dati kritičko mišljenje na iznesene interpretacije i analize prezentiranih povijesnih događaja. Budući da je planirao tiskati knjigu već krajem veljače ili početkom ožujka 1960. Jareb je zamolio za što žurniji odgovor na njegovu zamolbu, te istaknuo kako bi ga veselilo "ako bi se na raspravu javno osvrnuli u HR (Hrvatskoj reviji)". ${ }^{8}$ Pred kraj pisma Jareb je zaželio da njegova rasprava potakne

7 Riječ je o radu naslova Croatian King Tomislav defeated Bulgarian Emperor Symeon the Great on May 27, 927. koji je prvi put objavljen pod sličnim naslovom na hrvatskom jeziku u Hrvatskom kalendaru 1956. godine. Usp. DoMINIK MANDIĆ, "Koje je godine hrvatski kralj Tomislav pobijedio bugarskog cara Simeona Velikog?", u: Hrvatski kalendar, 13, Chicago, 1956., str. 132-141; ANDRIJA Nikić, Dr. fra Dominik Mandić, istaknuti hercegovački franjevac $i$ povjesničar, Bio-bibliografija, Zavičajna knjižnica, Mostar, 1981., str. 45-51; M. Jareb, "Mandićev odnos prema hrvatskoj (i inoj) političkoj emigraciji za vrijeme i nakon Drugoga svjetskog rata", str. 579-581, bilješka 34.

8 "U br. 4. HR, koga ćete uskoro dobiti avionski, nalazi se takodjer, treci i zavrsni dio moje rasprave "Pola stoljeća hrvatske politike" na 54 stranice. Ukupno sva tri dijela obuhvataju 115 stranica. Kanim cijeli tekst još revidirati, popraviti ga i proširiti, nanovo prelomiti i dodati opsirnu bibliografiju, te onda cijelu raspravu objaviti kao posebnu knjigu pocetkom 1960." AHFP, MO, sv. 7, m. 
fra Dominika, kao povjesničara koji zna vrjednovati važnost povijesnih memoara, na zapisivanje sjećanja, uspomena i ocjena političkih prilika vezanih uz Hercegovinu, posebice sjećanja vezanih za osnivanje i djelovanje Hrvatske pučke stranke u razdoblju od 1918. do 1928., u čijem je osnivanju i radu Mandić aktivno sudjelovao.

\section{Sadržaj pisane rasprave dvojice povjesničara na temu Pola stoljeća hrvatske politike (1895. - 1945.)}

Na Jarebovu zamolbu iz prethodno navedenoga pisma fra Dominik je pozitivno odgovorio 10. prosinca 1959. naglašavajući kako će radnju pročitati za vrijeme Božićnih blagdana a potom dostaviti svoja zapažanja i ocjenu u odnosu na iznesena autorova promišljanja. ${ }^{9}$ Već 10. siječnja 1960. uslijedilo je Mandićevo pismo u kojemu na četiri stranice iznosi svoje opaske o radu. Na samom početku pisma fra Dominik daje opću ocjenu kada je riječ o cjelokupnom sadržaju radnje tumačeći je "veoma dobrom i korisnom za upoznavanje najnovijih dogagjaja u hrvatskom narodnom i državnom životu i prema tome za ispravnu orientaciju sadašnjega naraštaja u njegovu narodnom radu". U nastavku pisma donosi također i primjedbe na neke autorove teze i zaključke. Tako, kada je riječ o jugoslavenstvu prije Prvoga svjetskog rata i poslije njega, Mandić osporava Jarebovu tvrdnju kako je "pred Prvi svjetski rat jugoslavenska ideja dominirala hrvatskom inteligencijom"10 tumačeći je preopćenitom i neopravda-

1, f. 100. Kada je riječ o korespondenciji između Mandića i Jareba, vezanoj za tematiku Pola stoljeća hrvatske politike, treba naglasiti da su sačuvana četiri pisma nastala u razdoblju od 23. studenoga 1959. do 19. siječnja 1960. Usp. AHFP, MO, sv. 7, m. 1, f. 107; sv. 7, m. 1, f. 5rv-6rv; sv. 11, m. 1, pm. 4, f. 14-17.

9 AHFP, MO, sv. 7, m. 1, f. 107. U istom pismu Mandić je odgovorio i na Jarebov poticaj vezan za pisanje uspomena i memoara gdje je istaknuo da bi se, unatoč svjesnosti o važnosti takvih zapisa, vrlo teško na taj pothvat odlučio, jer kada je u pitanju njegovo djelovanje u zemlji, nedostaje mu "vremenska i kronološka okosnica". Istaknuo je također kako je sva njegova korespondencija, iz koje se mogao steći uvid u vjerske, kulturne i političke prilike ne samo u Hercegovini nego i u Bosni, u razdoblju od 1915. do 1939. godine (21 svezak pisama) ostala na Širokom Brijegu što su komunisti, prema njegovim saznanjima, uništili tijekom zauzimanja Širokog Brijega, a ondašnje mostarske tiskovine i časopisi koji bi mu bili korisni za potaknuti sjećanja trenutačno su mu nedostupni.

10 Isto, sv. 7, m. 2, f. 5r. Usp. Jere Jareb, "Pola stoljeća hrvatske politike. Povodom Mačekove autobiografije, II. dio", u: Hrvatska revija, Buenos Aires, 
nom. U nastavku pisma uslijedilo je vrlo opširno pojašnjenje iznesene primjedbe u kojem stoji:

"a) Široki narodni slojevi bili su protiv razbijanju Austrije i stvaranju nove države sa Srbima zajedno. Oni naravnim osjećajem i stoljetnim iskustvom s domaćim Srbima nijesu vjerovali Srbima uopće i smatrali su pogibeljnim za Hrvate ujedinjenje sa Srbima u jednu zajedničku državu.

b) Gragjanski krugovi u većim gradovima i manjim varošicama, koji su dnevno čitali novine i mnogo politizirali, i većina hrvatske inteligencije, koja je bila odgojena u raznim pravaškim strankama, željeli su i tražili ujedinjenje hrvatskih zemalja i osnutak hrvatske države, koja bi stala u savezu s drugim narodnim državama pod žezlom hasburške monarhije. Za zajedničku državu bili su se Slovenci izjavili još godine 1912. Budući da je u hrvatskim zemljama živio veliki broj Srba, to se i njih htjelo pridobiti za zajedničku hrvatsku državu. U širokim gragjanskim krugovima i megju pravaškom inteligencijom tada se nije prihvaćalo načelo jednoga jedinstvenog naroda jugoslavenskoga. Istina, u Majskoj deklaraciji Jugoslavenskog kluba u Beču od 30. V. 1917. govori se o Slovencima, Hrvatima i Srbima kao 'jednom te istom narodu', ali se to smatralo kao diplomatski izražaj, da se mogne postići ujedinjenje svih hrvatskih zemalja (Banovine, Dalmacije, $\mathrm{BiH}$, Vojvodine, Istre, Megjumurja), kojoj bi se pridružila i Slovenija. Tada se u Americi govorilo o samoodregjenju svakoga naroda, radi toga se u javnim diplomatskim sastavcima moralo govoriti o jednom narodu SHS, ako se htjelo za sve postići jednu zajedničku državu. Mjesto tri naroda od tog doba počelo se često govoriti o trima plemenima, ali se tim 'plemenima' pridavalo sve značajke koje imaju pravi narodi. Za vrijeme rata gragjanstvo i pravaško odgojena inteligencija nije ni mislila na ujedinjenje sa Srbijom i Crnom Gorom u jednu državu. Za ljetnih praznika god. 1918. ja sam dva mjeseca, srpanj i kolovoz, proveo na putu od Mostara do Beča. U Sarajevu sam govorio s nadbiskupom Štadlerom, drom N. Mandićem, drom Sunarićem, T. Alaupovićem, O. J. Jelenićem. U Zagrebu sam se sastao s nadbiskupom Bauerom, kanonikom Barcem i Ritigom, drom Šimrakom, P. Roguljom, dr. I. Kršnjavijem. U Beču sam posjetio i

2/1959., str. 209; Isti, Pola stoljeća hrvatske politike (1895. - 1945.). Povodom Mačekove autobiografije, Institut za suvremenu povijest, Zagreb, 1995., str. 60. Riječ je o pretiskanom izdanju iz 1960. godine kojemu je autor dodao samo opširni pogovor na prvih 10 stranica teksta. 
razgovarao s drom Laginjom, prof. Spinčićem i drom Korošcem. Još tada se očekivalo, da će se ostvariti država SHS u granicama tadašnje A.-U. Dne, 5. i 6. listopada osnovano je u Zagrebu Narodno vijeće, kojem je ispred Hercegovine prisustvovao fra D. Buntić i Gj. Džamonja. Kada se O. Buntić povratio u Mostar, pričao mi je, da se u Zagrebu očekuje skori pad A-U, ali da se očekuje osnutak države SHS na čelu s engleskim princom od Kenta.

c) Mala grupa inteligencije napredno liberalne, većinom u Zagrebu i Splitu, pod vodstvom Marjanovića, Vildera i Smodlake, bila je jugoslavenska u pravom i punom značenju riječi. Za ovu samo skupinu vrijede riječi F. Perše u HR IX 500. Politički ova je grupa pripadala Naprednoj stranci, dotično Hrv.-srp. koaliciji.

d) Inteligencija Hrv. kat. pokreta spadala je u drugu grupu hrvatske inteligencije pod b), iako je u njoj bio neznatan broj uvjerljivih Jugoslavena. Većina te inteligencije potjecala je iz seljačkih i malogragjanskih krugova, pa je u duši mislila kao i seljački narod. Ali radi ugleda nekih vodećih ličnosti i radi jedinstvene discipline prihvaćala je smjernice rada, koje je donosilo vodstvo u Zagrebu."11

Stajalište Hrvatskoga katoličkog pokreta prema stvaranju zajedničke jugoslavenske države, koje je prema Mandićevim navodima, između ostaloga, bilo uvjetovano i poštivanjem smjernica zagrebačkoga vodstva, obrazložio je nekoliko redaka niže u istom pismu, i to s aspekta izravnoga sudionika, odnosno glavnoga predstavnika Hrvatskoga katoličkog pokreta u Hercegovini, gdje kaže:

"Ispad rata i 'ujedinjenje' sa Srbijom hrvatski seljački narod primio je s najvećom žalosti i negodovanjem. Gragjanski krugovi i ogromna većina inteligencije, napose Hrv. kat. pokreta, to je primila sa zabrinutošću. Megju tim i ja sam tako osjećao. Ja sam tada bio predsjednik Hrv. kat. seniorata u Mostaru i glavni predstavnik Hrv. kat. pokreta u Hercegovini. Prvaci Hrv. kat. pokreta u Zagrebu osiguravali su, da se ne treba ništa bojati. Hrvati su prosvjetno i gospodarstveno napredniji i imat će vidnu, dapače vodeću ulogu u novoj državi. Hrvati katolici valja da lojalno suragjuju u novoj državi i tim da Srbima pokažu, da Hrvati nijesu protiv države. Na taj će se način izbjeći kulturnoj borbi izmegju Hrvata i Srba i tim poslužiti općim interesima hrvatskog naroda. I megju prvim crkvenim ljudima u Zagrebu i Ljubljani bilo je ljudi, koji su se zanosili mišlju, da će Srbi, bolje upoznav-

11 AHFP, MO, sv. 7, m. 2, f. 5rv. 
ši katolicizam preko Hrvata i Slovenaca, pristupiti uniji i tim postati uzor i preteče ujedinjenja svih Slavena s katoličkom Crkvom."12

Posljednja stavka pod prvom točkom pisma, kada je riječ o odnosu hrvatskoga naroda prema jugoslavenskoj ideji i stvaranju zajedničke države, odnosi se na političku emigraciju odnosno na Jugoslavenski odbor. Prema fra Dominikovu mišljenju:

e) "'Jugoslavenski odbor' u Londonu na čelu s drom Trumbićem, kako je poznato, prihvatio je misao jednoga naroda jugoslavenskoga iz nužde, da spasi hrvatske primorske zemlje od Talijana. Vodio je veliku propagandu u Južnoj i Sjevernoj Americi i za svoju misao pridobio je bogatije ljude u tim zemljama. U Južnoj Americi uz tu je misao pristao veliki broj i radnog svijeta iz Hrvatske, napose iz Dalmacije. Ali u Sjevernoj Americi tu je ideju zabacivalo hrvatsko radništvo listom. Ti su općenito htjeli i željeli hrvatsku državu u okviru Austrije. Predvodili su ih Franjo Zotti sa svojim 'Narodnim Listom' i Ivan Krešić sa 'Danicom' u N. Y. Od hrvatskih svećenika isticali su se napose u borbi za hrvatsku državu rev. Davorin Krmpotić, župnik u Kansas City, Dr Mirko Kaić, župnik Johnstownu, rev. Ante Žuvić, župnik u Steeltonu, Rev. fra Leo Medić, župnik u St. Jerome, Chicago, Rev. Irinej Petriček, župnik u N. Y. Rev. Krmpotić napisao je u sred rata, kada je bila propaganda Jugoslavenskoga odbora i srpske vlade na vrhuncu, brošuru na engleskom jeziku pobijajući pretenzije Srbije na BiH, koje su hrvatske zemlje i imaju pripasti hrvatskoj državi. Naslov je djela: Croatia Bosnia and Herczegovina and the Serbian claims, Kansas City, Kansas, 1916. (kurziv aut.)". ${ }^{13}$

Stoga, na osnovi iznesenoga, Mandić zaključuje:

"Prva je Jugoslavija stvorena protiv i mimo očekivanja hrvatskoga seljačkoga naroda, ogromne većine i gragjanskoga svijeta i hrvatske inteligencije. $\mathrm{Za}$ to odgovornost nose saveznici, koji su pobijedili u

12 Isto, sv. 7, m. 2, f. 5v. Zanimljivim se čini ovaj citat usporediti s dijelom pisma fra Dominika Mandića iz srpnja 1968. godine u kojemu autor, na zamolbu Ivana Mužića, donosi svoja sjećanja o stavu Hrvata katolika iz BiH, HKP i HPS prema stvaranju KSHS gdje stoji: "Stvorenom stanju ispadom rata i novoj državi pozitivno je pristupila hrvatska inteligencija u velikoj većini u svim krajevima. Tako i pismeniji dio građanskog pučanstva. Međutim Hrvati seljaci posvuda, među njima i katolici i muslimani u Bosni i Hercegovini, s velikim su nepovjerenjem gledali u budućnost nove države..." Usp. Ivan Mužıć, Katolička crkva, Stepinac i Pavelić, Marjan tisak d.o.o., Split, ${ }^{32003 ., ~ s t r . ~} 452$.

13 AHFP, MO, sv. 7, m. 2, f. 5v. 
ratu i Jugoslavenski klub u Londonu. Za bezuvjetno ujedinjenje na 1. prosinca 1918. nosi odgovornost Sv. Pribićević, koji je izigrao Hrvatski sabor i Narodno Vijeće u Zagrebu, da provede 'ujedinjenje' sa Srbijom po Karagjorgjevićima." ${ }^{14}$

Dobra stvar je što u sačuvanoj korespondenciji nalazimo i Jarebov odgovor na Mandićeve primjedbe i donesena tumačenja. Dakle, 19. siječnja 1960. Jere Jareb upućuje pismo fra Dominiku (četiri stranice teksta) u kojemu mu ponajprije zahvaljuje na uloženu trudu i konstruktivnim primjedbama, a potom se osvrće na prvu točku Mandićeva pisma kako bi eventualno došli "do više jasnoće u [našim] pogledima". ${ }^{15}$ Kako se iz sadržaja pisma vidi, Jareb u potpunosti podržava Mandićevu tezu da su široki narodni slojevi, poučeni iskustvom i nepovjerenjem prema Srbima, bili protiv razbijanja Austro-Ugarske i ujedinjenja u zajedničku državu sa Srbima. ${ }^{16}$ Međutim, kada je riječ o začetku i širenju ideje narodnoga jedinstva i zajedničke države u krugovima hrvatske inteligencije, građanstva, sveučilišne mladeži i hrvatskih političkih predstavnika, promišljanja dvojice povjesničara donekle se razlikuju. Naime, Mandić naglašava kako u prijeratnom razdoblju, među građanstvom i pravaškom inteligencijom, nije se "prihvaćalo načelo jednoga jedinstvenoga naroda jugoslavenskoga", bez obzira na Svibanjsku deklaraciju i spominjanje Slovenaca, Hrvata i Srba kao jednoga naroda, budući da je to, prema Mandiću, služilo samo "kao diplomatski izražaj, da se mogne postići ujedinjenje svih hrvatskih zemalja (Banovine, Dalmacije, $\mathrm{BiH}$, Vojvodine, Istre,

14 Isto, sv. 7, m. 2, f. $5 \mathrm{v}$.

15 Isto, sv. 11, m. 1, pm. 2, f. 14-17. Usporedbom i analizom promišljanja dvojice uglednih povjesničara kroz njihovu korespondenciju vezanu za Jarebovo djelo Pola stoljeća hrvatske politike (1895. - 1945.). Povodom Mačekove autobiografije nastoji se čitateljima približiti njihova stajališta o pojedinim "spornim" pitanjima, ali također, prateći u sadržajnom smislu kako radove objavljene u tri broja Hrvatske revije iz 1959. godine na temelju kojih je Mandić iznosio svoje primjedbe i sugestije, tako i objavljene knjige nakon toga, i spoznati u kojoj su mjeri zapravo Mandićeva promišljanja utjecala na autorovo konačno izneseno stajalište.

16 Ova teza sadržana je kako u njegovu objavljenom radu, tako i u kasnije objavljenoj knjizi. "Hrvatski narod u svojoj ogromnoj većini nije nikad želio državne zajednice sa Srbijom. Ta odbojnost prema Srbiji bila je samo povećana nepametnom srpskom politikom...". Usp. Jere JAREB, "Pola stoljeća hrvatske politike. Povodom Mačekove autobiografije, I. dio", u: Hrvatska revija, Buenos Aires, 1/1959., str. 30; J. JAREB, Pola stoljeća hrvatske politike. Povodom Mačekove autobiografije, str. 23. 
Megjumurja), kojoj bi se pridružila i Slovenija", dok u ratnom razdoblju, kako tvrdi, "gragjanstvo i pravaško odgojena inteligencija nije ni mislila na ujedinjenje sa Srbijom i Crnom Gorom u jednu državu", što potkrjepljuje informacijama sa sjednice Narodnoga vijeća održane početkom listopada 1918., gdje se raspravljalo o očekivanom raspadu Austro-Ugarske i osnutku Države SHS. ${ }^{17} \mathrm{~S}$ druge strane Jareb smatra kako treba razlikovati proces začetka, širenja i prihvaćanja ideje narodnog jedinstva od ideje zajedničke države sa Srbijom i Crnom Gorom. Prema njegovu mišljenju, "ideja narodnog jedinstva izmedju Hrvata, Srba i Slovenaca, pocevsi od 1895. pa do 1918. sve vise raste i siri se medju hrvatskim studentima, intelektualcima i politicarima". Ta je ideja, kako naglašava, "zahvatila prije 1918. sve hrvatske stranke, politicke grupe, i vrlo velik dio inteligencije i gradjanstva". ${ }^{18}$ Međutim, kada je riječ o ideji zajedničke države sa Srbijom i Crnom Gorom izvan Austro-Ugarske, Jareb se slaže s Mandićevim mišljenjem da ta ideja "nije još prihvaćena od većine hrvatskih političara ni početkom listopada 1918.", ${ }^{19}$ ali jednako tako drži da je "medju

17 AHFP, MO, sv. 7, m. 2, f. 5r.

18 Isto, sv. 11, m. 1, pm. 2, f. 14. "Nove sile, koje ulaze u politički život 1902.-1905., sve bez iznimke prihvaćaju fikciju narodnog jedinstva Hrvata i Srba. Ta je fikcija zajednička i liberalcima i klerikalcima i socijalistima. Ona je jednako kod kuće i kod katoličkog pokreta, i kod napredne i kod socijalističke stranke. Njoj se nije otela ni Seljačka Stranka, nego ju je i ona prihvatila." Usp. J. JAREB, "Pola stoljeća hrvatske politike. Povodom Mačekove autobiografije, I. dio", str. 25-26; Isti, Pola stoljeća hrvatske politike. Povodom Mačekove autobiografije, str. 17.

19 AHFP, MO, sv. 11, m. 1, pm. 2, f. 14. U svojim uradcima Jareb je to izrazio na sljedeći način: "Idejna fikcija narodnog jedinstva dovela je pak s vremenom, logično, do ideje jedne, jedinstvene narodne države, Jugoslavije. Činjenica je svakako, da ideja jedne, jedinstvene hrvatsko-srpske države nije još prisutna kod stranačko-političke pregrupacije, 1903.-1905. Čini se da je ideja hrvatske države još uvijek vodstvena i u hrvatskoj politici..." Usp. J. JareB, "Pola stoljeća hrvatske politike. Povodom Mačekove autobiografije, I. dio", str. 26; IsTi, Pola stoljeća hrvatske politike. Povodom Mačekove autobiografije, str. 17-18. Ovu nelogičnost prihvaćanja srpsko-hrvatskoga narodnog jedinstva, ali i borbe za posebnu hrvatsku državu, Jareb objašnjava činjenicom da su "ondašnji pristaše hrvatsko-srpskog narodnog jedinstva mislili zapravo samo na srpsku manjinu u Hrvatskoj, a potpuno zaboravljali Srbijance i Crnogorce... Uključivanje Srbijanaca i Crnogoraca u taj koncept poslije godine 1908. odvodi veliki dio pristaša koncepcije hrvatsko-srpskog narodnog jedinstva s linije hrvatske državnosti na liniju jugoslavenske državne ideje". Usp. Istı, "Pola stoljeća hrvatske politike. Povodom Mačekove autobiografije, I. dio", str. 27, bilješka 17; IsTi, Pola stoljeća hrvatske politike. Povodom Mačekove autobiografije, str. 19, bilješka 16. 
hrvatskom sveucilisnom i srednjoskolskom omladinom dobivala sve vise pristasa od 1908. pa do 1918.", odnosno da je ta ideja tijekom rata i 1918. godine "dominantna medju mladjim intelektualcima". ${ }^{20}$ Prema Jarebovu mišljenju navedeni koncept svojstven je i katoličkom pokretu, a o političkim pogledima mlađe generacije i samoga biskupa Antuna Mahnića, kako je istaknuo, može se mnogo toga saznati iz ondašnjih Riječkih novina, kasnije preimenovanih u Novine (sjedište od rujna 1914. u Zagrebu), čiju su uređivačku politiku vodili pripadnici katoličkoga seniorata. ${ }^{21} \mathrm{U}$ tom smislu donosi stajališta dr. Janka Šimraka, istaknutoga člana Katoličkoga pokreta, predstavnika Novina, ali i člana Središnjega odbora Narodnoga vijeća, te člana delegacije koja je putovala u Beograd na dogovor oko ujedinjenja. Dakle, na temelju publiciranih zapisnika Narodnoga vijeća, Jareb tvrdi kako je Šimrak "u debatama NV bio blizi Koaliciji i Pribicevicu nego starcevicanima". U prilog tome govori i njegovo protivljenje ulasku frankovaca u Narodno vijeće. Osim toga prema Jarebovu navodu "na sjednici NV od 24. XI. 1918. Simrak je urgirao da se provede jedinstvo sa Srbijom cim prije". 22

Jareb je u svom pismu također osporio i Mandićevu tezu kako je Jugoslavenski odbor prihvatio "misao jednoga naroda jugoslavenskoga iz nužde, da spasi hrvatske primorske zemlje od Talijana". On naime, smatra kako su Trumbić i Supilo, odnosno Jugoslavenski odbor "tu misao prihvatili cijelu jednu dekadu prije rata", a odlaskom u emigraciju "odmah su izisli s idejom rusenja Austro-Ugarske i zajednicke drzave sa Srbijom", a takva politika "zapravo je onemogućila obranu

20 AHFP, MO, sv. 11, m. 1, pm. 2, f. 14. Ovaj stav u radu odnosno, kasnije u knjizi, iskazan je formulacijom: "Od aneksije Bosne i Hercegovine, srpskog i Friedjungovog procesa, i posebice za vrijeme balkanskih ratova ideja jedinstvene hrvatsko-srpske države sve više jača i širi se medju hrvatskom školskom mladeži. Ali i u tom razdoblju, čini se, ona još uvijek nije vodstvena u hrvatskoj politici". Usp. J. Jareb, "Pola stoljeća hrvatske politike. Povodom Mačekove autobiografije, I. dio", str. 26; Isti, Pola stoljeća hrvatske politike. Povodom Mačekove autobiografije, str. 18.

21 Zlatko Matıjević, "Hrvatski katolički pokret i politika (1903.-1929.)", u: Croatica christiana periodica, 47, Zagreb, 2001., str. 183-184; JURE KRIŠTO, Hrvatski katolički pokret 1903.-1945., Hrvatski institut za povijest, Zagreb, 2004., str. 82-85, 103.

22 Jareb u svome pismu donosi citat Šimrakova govora s navedene sjednice Narodnoga vijeća preuzetog iz časopisa Starine (br. 48, str. 373) u kojem stoji: "Mi moramo da imademo jaku centralnu zajednicku vladu. To traži od nas unutrasnji polozaj. Danas je u nas potpuni darmar. Mi ne mozemo rijesiti ni 
hrvatske Jadranske obale", jer prema njegovu mišljenju, da se Jugoslavenski odbor nije povezao sa Srbijom "nema sumnje da ne bi bili dobili medjunarodno priznanje od Saveznika i vec prije konca rata uspjeli rijesiti, povoljnije nego u Rapallu, hrvatsko-slov. i talijansku granicu. Medjunarodno priznanje JO razbilo se je jedino na odporu Srbije. Italija je bila spremna provesti to priznanje poslije izjave tal. vlade od 8. IX. 1918.", pa stoga Jareb zaključuje kako su Meštrovićevi i Trumbićevi argumenti poslije 1918. "slaba [su] obrana njihove politike, jer su činjenice drugačije". ${ }^{23}$

Iako se u navedenom pismu Jareb nije osvrnuo na Mandićev komentar kako za stvaranje prve Jugoslavije "odgovornost nose saveznici, koji su pobijedili u ratu" iz sadržaja objavljenog rada, a kasnije i knjige, jasno je kako ne prihvaća navedenu tezu, nego štoviše, citirajući bilješke jednoga Wilsonova razgovora o nacrtu ustava Lige naroda, javnosti prezentira i Wilsonovu razmatranu opciju podjele jugoslavenske države, pa stoga ističe kako je potrebno "detaljno proučiti stanovišta ondašnjih velikih sila o stvaranju Kraljevine SHS, a ne ponavljati netočnu tezu, da su zapadne sile krive za njezino stvaranje i gospodstvo Srba nad Hrvatima". ${ }^{24}$

jednog pitanja, koje malo dublje zasijeca u nas nacionalni zivot bez zajednicke centralne vlade... Cini se, da je današnja vlada Narodnoga vijeca samo zato tu, da daje mjesecne place birokratima i paragrafasima, dok je to moguće." Usp. AHFP, MO, sv. 11, m. 1, pm. 2, f. 15. Opširnije o odnosu katoličkoga pokreta i ideologiji jugoslavenstva vidjeti: JURE KRIŠTO, Prešućena povijest. Katolička crkva u hrvatskoj politici 1850.-1918., Hrvatska sveučilišna naklada, Zagreb, 1994., str. 288-289, 310-312; IsTi, Hrvatski katolički pokret 1903.-1945., str. 105-115; Z. MATiJević, "Hrvatski katolički pokret i politika (1903.-1929.)", str. 183-188; Isti, "Politička orijentacija Hrvatskog katoličkog pokreta u posljednjim godinama postojanja Austro-Ugarske Monarhije i prvim danima stvaranja Kraljevstva SHS (1903.-1918.)", u: Društvena istraživanja. Časopis za opća društvena pitanja, Zagreb, 1-2/2001., str. 147-155.

23 AHFP, MO, sv. 11, m. 1, pm. 2, f. 15.

24 Riječ je o bilješkama Wilsonova razgovara o nacrtu ustava Lige naroda sa sastanka od 30. siječnja 1919., u kojem je, pojašnjavajući koncept jednog paragrafa, rekao "da je razlog zašto je paragraf sastavljen u toj formi to što bi Jugoslavija mogla biti podijeljena u jednu, dvije ili tri države. On je spreman pripustiti dvije jugoslavenske države u Ligu Naroda, ali, ako bi se našlo uputnim podijeliti ih u tri dijela, on bi više volio staviti neoblikovaniju i manje razvijenu od novih država pod mandat Lige Naroda". Usp. J. JAREB, "Pola stoljeća hrvatske politike. Povodom Mačekove autobiografije, I. dio", str. 31, bilješka 22; Isti, Pola stoljeća hrvatske politike. Povodom Mačekove autobiografije, str. 23-24, bilješka 22 . 
Drugu točku već spomenutoga pisma, a koja se odnosi na Hrvatsku pučku stranku (HPS), ${ }^{25}$ Mandić je započeo kritizirajući Jarebovo rezoniranje kada je riječ o političkim opredjeljenjima ove stranke. Ono što je Mandiću smetalo svakako su Jarebovi navodi izneseni u članku, a kasnije u nešto ublaženijoj formi ponovljeni i u knjizi gdje piše: "Pučka Stranka po svojoj politici i programu bila je bliža ideji jugoslavenske države od ostalih triju stranaka katoličkih Hrvata. Moglo bi se čak reći, da je bila jedina hrvatska stranka s jugoslavenskom orientacijom u tom razdoblju", argumentirajući to i činjenicom kako je "njezin predstavnik ušao [je] u Koroščevu vladu, sastavljenu poslije atentata u skupštini, dok su predstavnici Federalističke stranke i Stranke Prava ušli u HSS. Pučka Stranka izuzevši JMO, jedina se je u tom času oglušila složnoj hrvatskoj fronti", pa stoga Jareb zaključuje kako "bi bilo bolje, da ta stranka uopće nije ni postojala, a da su organizirani katolici i svećenstvo sudjelovali u radu ostalih hrvatskih stranaka". ${ }^{26}$ Osporavajući, dakle, ovakvo promišljanje, fra Dominik je ustvrdio kako je "od svoga osnutka god. 1919. do svoga raspusta god. 1928. HPS i po imenu i po programu i radu, bila [je] prava hrvatska stranka, a nikako jugoslavenska. U programu HPS poimala je hrvatski narod kao svoj individualni narod, različit od Srba i Slovenaca... Zastupnici HPS radili su protiv donesena Vidovdanskoga ustava i s drugim hrvatskim zastupnicima ostavili su Beograd prije nego je izglasan Vidovdanski ustav". ${ }^{27}$ Osim toga Mandić je ustvrdio kako su osnivači, čijim je članom i on bio, HPS zamišljali kao političku stranku "hrvatskoga naroda sa izrazito socijalnim kršćanskim

25 Opširnije o HPS-u vidjeti u: Zlatko Matıjević, Slom politike katoličkog jugoslavenstva. Hrvatska pučka stranka u političkom životu Kraljevine SHS (1919.-1929.), Hrvatski institut za povijest, Zagreb, 1998.; Isti, "Hrvatska pučka stranka", u: Hrvatska revija, Zagreb, 3/2003., str. 78-89; IsTi, "Hrvatska pučka stranka i Stjepan Radić (1919.-1928.)", u: Radovi Zavoda za hrvatsku povijest Filozofskog fakulteta Sveučilišta u Zagrebu, 32-33, Zagreb, 2000., str. 257-266.

26 J. JAReb, "Pola stoljeća hrvatske politike. Povodom Mačekove autobiografije, I. dio", str. 33. Izmijenjena formulacija u knjizi glasi: "Pučka Stranka po svojoj politici bila je bliža ideji jugoslavenske države od ostalih triju stranaka katoličkih Hrvata. Njezin predstavnik ušao je u Koroščevu vladu, sastavljenu poslije atentata u skupštini, dok su predstavnici Federalističke stranke i Stranke Prava ušli u HSS. Pučka Stranka izuzevši JMO, jedina se je u tom času oglušila složnoj hrvatskoj fronti." Usp. Isti, Pola stoljeća hrvatske politike. Povodom Mačekove autobiografije, str. 26.

27 AHFP, MO, sv. 7, m. 2, f. 5v-6r. 
programom kao što je bio u to vrijeme njemački Centrum, austrijska i belgijska kršćansko socijalna stranka, a u Italiji Popolari don L. Sturza". Razlog zbog kojega ova stranka nije opstala u Hrvatskoj, Mandić vidi u političkom kompleksu Hrvata nakon Prvoga svjetskog rata, odnosno zato što je hrvatski narod "u to doba nagonski osjećao, da je njemu i kao narodu, i za njegovu vjeru i kulturu, najveći neprijatelj velikosrpstvo oličeno u srpskoj svetosavskoj crkvi, srpskom Karagjorgjevića dvoru, u srpskoj vojsci, u državnoj zajednici sa Srbima", pa se zbog toga priključio HRSS-u, "jer je ta propovijedala razlaz sa Srbima i osnutak samostalne hrvatske države. I čim hrvatski narod dobije mogućnost slobodnoga izraza, on će poći za onom strankom, koja će tražiti punu slobodu Hrvatske". ${ }^{28}$

Prema Mandiću, neispravna je i Jarebova tvrdnja kako je politički nastup HPS-a proizveo "pravu kulturnu borbu na hrvatskom selu"29 jer, prema njegovim navodima, kulturnu borbu u hrvatski javni život unijeli su "naprednjaci, učenici Masarykovi, megju kojima je bio i Stjepan Radić.... koji se nije dao nagovoriti ni u smrtnoj pogibli, da primi kršćanske sakramente". ${ }^{30}$ Upravo je ovakav "Radićev vjerski liberalizam", po Mandićevu mišljenju, bio jedan od glavnih razloga nepovjerenja svećenika prema njemu i njegovoj politici. Stoga Mandić zaključuje kako "HPS nije izazivala kulturnu borbu u hrvatskom narodu, nego je nastojala, da narod od toga liječi, dotično da zapriječi daljne širenje pogubnoga vjerskoga liberalizma".

U posljednjoj, trećoj točki pisma fra Dominik skreće pozornost na članak "Promašeni kriteriji" objavljen u Danici, 13. siječnja 1960., u kojem se anonimni autor kritički osvrnuo na objavljene Jarebove radove, navodeći kako i sam smatra "da stvarno uglavnom ima pravo", jer da bi i on, kada ne bi poznavao svjetonazore autora "po [Vašem] pisanju u ovoj radnji o HPS, o Hrv. kat. pokretu, o novinarskoj katoličkoj skupini, itd., mislio [bih], da ste vjerski liberalac, antikatolički raspoložen". ${ }^{31}$

28 Isto, sv. 7, m. 2, f. 6r.

29 "Hrvatska pučka stranka, stranka katoličkog pokreta, otimala se je zajedno s HSS-om za glasove seljaka. Razumije se, da je to onda više puta proizvelo pravu kulturnu borbu na hrvatskome selu, koja je sigurno bila štetna vjeri i pravim narodnim interesima." Usp. J. JAREB, "Pola stoljeća hrvatske politike. Povodom Mačekove autobiografije, I. dio", str. 33; Isti, Pola stoljeća hrvatske politike. Povodom Mačekove autobiografije, str. 26.

30 AHFP, MO, sv. 7, m. 2, f. 6r.

31 Isto. 
Mandić svoje pismo završava još jednom primjedbom koja se odnosi na dijelove rada u kojima je obrađeno političko i kulturno djelovanje u hrvatskoj emigraciji, zamjerajući autoru nespominjanje nekih organizacija poput Hrvatske bratske zajednice, te neuključivanje $u$ svoja razmatranja utjecaja hrvatskoga novinstva u SAD-u, posebice listova: Danica, Hrvatski list, Narodni list koji je kasnije prerastao u Jugoslavenski list, koji su, prema njegovu mišljenju, daleko važniji i "za hrvatsku budućnost sudbonosniji". ${ }^{2}$

Iako je nedvojbeno, prema sačuvanoj korespondenciji, Jareb cijenio fra Dominikov znanstveni rad čini se ipak kako njegove primjedbe nisu značajnije utjecale na već formulirana Jarebova razmatranja. Naime, Mandićevu poprilično oštru kritiku Jarebovih stajališta oko HPS-a, autor je, u svom pismu (19. siječnja 1960.) odbacio argumentirajući svoje teze djelom Ive Guberine, Katolički pokret u Hrvatskoj, u kojemu je donesen i program HPS-a, a, kako Jareb ističe, "u tom programu je bilo naglaseno jugoslavensko narodno jedinstvo". S druge pak strane ponovio je svoju tvrdnju "da je Radicu jedina hrvatska konkurencija na selu bila HPS, jer Zajednicari i Pravasi nisu zalazili u sela", što po njegovoj prosudbi nameće zaključak "da Radicevo anti-katolicko, anti-svecenicko nastupanje na selima ne bi bilo došlo do izražaja, da nije bilo te konkurencije", koja je zasigurno politički bila štetna. Ovo je potkrijepio i primjerom svoga rodnoga sela Šepurine (kotar Šibenik) gdje je HRSS/HSS na svim izborima od 1923. do 1927. godine dobivala preko $80 \%$ glasova, dok su HPS-ovi izborni rezultati bili poražavajući. Prema njegovim podatcima za Šepurine, HPS je na izborima 1927. godine dobila svega 17 glasova, zahvaljujući svećeniku don Srećku Paviću, što je u konačnici dovelo do toga da se svećenik "odijelio od naroda i sigurno uvelike kasnije pripomogao komunističkoj propagandi". Jareb podsjeća fra Dominika na vrlo sličnu situaciju i u Hercegovini kada je riječ o izbornoj utrci između HPS-a i HRSS-a odnosno HSS-a retoričkim pitanjem "zašto je Hercegovina 1923. i kasnije glasovala za HRSS a ne za HPS, koju su tamo predstavljali njeni sinovi franjevci?"33 Svoja promišljanja po ovom pitanju završio je konstatacijom dr. Merza koji je, po njegovoj prosudbi,

32 Isto.

33 Osim navedenoga Jareb ukazuje na još neke nejasnoće u politici HPS-a kao što su njezino nesudjelovanje u Hrvatskom bloku 1921. - 1923. godine, te ulazak Stjepana Barića u koalicijsku vladu dr. Antona Korošca 1928. godine. Usp. AHFP, MO, sv. 11, m. 1, pm. 2, f. 15. 
"bolje od ostalih uocio, da hrvatski narod ne zeli vidjeti svecenika u politici i da ne zeli mijesanje vjere i politike, a tako se je, čini mi se, shvatila pojava HPS u širokim narodnim slojevima".

Svakako, vrlo zanimljivo bi bilo pročitati i fra Dominikovo razmišljanje, koje je sugerirao i sam Jareb u navedenom pismu, po pitanju odnosa hrvatske politike prema muslimanima. Naime, Jareb je, u trećem, završnom dijelu svoje rasprave, ponudio i neka pitanja na razmatranje i diskutiranje, a jedno od njih odnosilo se na hrvatsku politiku prema, kako ih naziva, Hrvatima muslimanima, i to ne samo u ondašnjoj Hrvatskoj nego i u Bosni i Hercegovini, koncipirajući ovu problematiku na sljedeći način:

"Hrvatski narod je vjerski složen narod. Ne može ga se identificirati s nijednom vjerom. Predstavnici hrvatskog katolicizma mogu govoriti samo u ime katolika, a ne u ime cijelog naroda, i identificirati katolicizam s hrvatstvom. Takva identifikacija u prošlosti izravno je škodila hrvatskoj narodnoj zajednici, a, prema tome, i hrvatskim katolicima." 34

Obrazlažući u pismu ovu svoju formulaciju Jareb polazi od konstatacije kako "Hrvati katolici" premalo vode računa o tome da u "povijesnoj Hrvatskoj" čine tek nešto više od 50\% pučanstva, zanemarujući, po njemu, bitnu činjenicu "da su muslimani isto tako Hrvati". Prema njegovu mišljenju "katolici i muslimani vezani su na zivot i smrt u Bosni i Hercegovini, a bez $\mathrm{BiH}$ tesko je zamisliti jednu samostalnu Hrvatsku". ${ }^{35} \mathrm{~S}$ druge strane Jareb smatra kako je bitka s pravoslavljem na hrvatskom prostoru izgubljena, jer je, kako naglašava, zbog ranog identificiranja hrvatstva i katolicizma, ono zaživjelo kao "srpsko pravoslavlje". Stoga Jareb promišlja kako "bi većina pravoslavaca u povijesnoj Hrvatskoj bila hrvatske nacionalne orientacije", da je već

34 Jere Jareb, "Pola stoljeća hrvatske politike. Povodom Mačekove autobiografije, III. dio", u: Hrvatska revija, Buenos Aires, 4/1959., str. 444.

35 Ova promišljanja treba promatrati u kontekstu vremena i okruženja u kojemu su izgrađivana, svakako, imajući u vidu političke programe muslimanskih organizacija u emigraciji. Usp. AHFP, MO, sv. 11, m. 1, pm. 2, f. 16; J. JAREB, "Pola stoljeća hrvatske politike. Povodom Mačekove autobiografije, III. dio", str. 440-442; Isti, Pola stoljeća hrvatske politike. Povodom Mačekove autobiografije, str. 134-136. 
1860-ih godina "doslo do stvaranja Hrv. Pravoslavne Crkve u Zagrebu" što bi opet s vjerskoga stajališta pospješilo "pitanje unije izmedju pravoslavlja na hrv. teritoriju i katolicizma". ${ }^{36}$

$\mathrm{Na}$ žalost, u sačuvanoj korespondenciji ne nalazimo izravni Mandićev odgovor na ovu potaknutu Jarebovu diskusiju, ${ }^{37}$ međutim iz sadržaja raznih pisama, ${ }^{38}$ te većega broja povijesnih rasprava objavljenih u emigraciji, neupitan je njegov stav o hrvatskom etničkom podrijetlu bosansko-hercegovačkih muslimana. Vrhunac u dokazivanju ove teze svakako je djelo Etnička povijest Bosne i Hercegovine ${ }^{39}$ koja se u javnosti pojavila 1967. godine, u jeku rasprave o priznavanju muslimana kao posebne nacije u drugoj Jugoslaviji.

36 AHFP, MO, sv. 11, m. 1, pm. 2, f. 16. Pozivajući na otvorenu raspravu o problemu srpske manjine u Hrvatskoj, Jareb smatra kako bi trebalo analizirati i "povijesni postanak srpske nacionalne svijesti kod pravoslavaca u Bosni, Dalmaciji, Hrvatskoj i Slavoniji", jer on smatra "da su se pravoslavci na hrvatskom teritoriju u XIX. Stoljeću mogli orijentirati nacionalno hrvatski, da je u tom pogledu bilo pametne i realne hrvatske politike". Usp. J. JAREB, "Pola stoljeća hrvatske politike. Povodom Mačekove autobiografije, III. dio", str. 443.

37 Sljedeće pismo između dvojice povjesničara datirano je 26. rujna 1961., a u sadržajnom smislu nema nikakve veze s ovom tematikom. Ni u ostaloj sačuvanoj korespondenciji ova pitanja nisu više aktualizirana.

38 Ovdje donosimo dijelove pisma koje je fra Dominik u kolovozu 1954. godine uputio Društvu bosansko-hercegovačkih i sandžačkih Hrvata muslimana u kojem stoji: "Veseli me, da B.H Muslimansko društvo u Engleskoj i Vaš list u Engleskoj zastupaju otvoreno hrvatsko stanovište. Muslimani B. i H. su Hrvati po krvi, žive unutar hrvatskoga državnog teritorija i opstanak im je i budućnost tjesno povezana s hrvatskim narodom, pa ne mogu i ne smiju da idu nego s Hrvatima". Usp. AHFP, MO, sv. 6, m. 1, f. 339.

39 Dominik Mandić, Etnička povijest Bosne i Hercegovine, Hrvatski povijesni institut, Rim, 1967. 


\section{Half a Century of Croatian Politics (1895-1945) in the correspondence between Dominic Mandic and Jere Jareb}

\section{Summary}

Preparing the publication of Jareb's book titled Half a Century of Croatian Politics (1895-1945) - on the Occasion of Macek's autobiography, which was based on the synthesis and the elaboration of the same work published in three parts in Hrvatska revija (Croatian Review), the author, as he emphasized in the book's preface, trying to depict this turbulent period of Croatian history as objectively as possible, asked several people for a more critical opinion, among whom the historian Fr. Dominik Mandic. There were four letters in the saved correspondence, which testified about the polemics between the two historians, especially regarding the Yugoslav national and state idea, and the position of the Catholic Movement and the Croatian People's Party on this issue. Although Mandic's critical review appeared with a relatively satisfactory time distance when it comes to a historical analysis of disputable issues, especially given the HPS situation, which disappeared from the political scene in 1929, or the beginning of the Croatian Catholic Movement. However, it can be concluded from Jareb's presented counterarguments that he recognized in Mandic's review a dose of non-objectivism when it comes to defending former political orientations.

Keywords: Dominik Mandic, Jere Jareb, Yugoslavism, Croatian politics, Croatian People's Party, Croatian Catholic movement. 